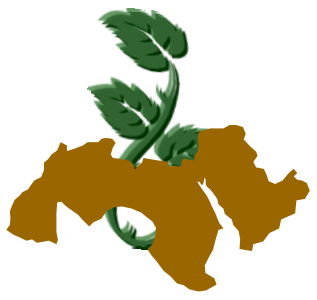

Arab Univ.

J. Agric. Sci.,

Ain Shams Univ.,

Cairo, 16(1), 213-224, 2008

\title{
USE OF WATER HYACINTH (Eichornia crassipes) IN AMELIORATION OF A SANDY SOIL
}

\author{
${\text { Mubarak*1, A.R.; Fattoma. A.M. Rezik }{ }^{1} \text { and S.A. Afiah }}^{2}$ \\ 1- Department of Soil and Environment Sciences, Faculty of Agriculture, University of Khartoum, \\ Shambat P.O. Box 32, Sudan \\ *Present Address: Desertification and Desert Cultivation Studies Institute, University of Khar- \\ toum, Shambat, Sudan. (e mail: mubarakaba@yahoo.com) \\ 2- Desert Research Centre, El-Mataria, Cairo, P.O. Box 11753, Egypt
}

Keywords: Arid soils; Decomposition; Sudan; Water hyacinth

\begin{abstract}
Soil fertility management is a key issue for sustaining agricultural production in dry lands. Organic resources are important for nutrient availability and maintenance of soil organic matter. Sustaining fertility of arid soils necessitates increasing inputs of organic residues. Two experiments with water hyacinth were carried out to monitor (in the first; field study with litter bags) decomposition and changes in $\mathrm{N}, \mathrm{P}, \mathrm{K}, \mathrm{Ca}$ and $\mathrm{Mg}$ as influenced by method of application where, in the second (greenhouse study) short-term effect on some properties of a sandy soil and early establishment of fodder sorghum (Sorghum bicolor) Results of the first experiment showed that residues incorporated in the top $0-30 \mathrm{~cm}$ soil depth had significantly $(\mathrm{P} \leq 0.01)$ increased loss of dry matter weight compared to surface application. Decomposition rate constants of surface and sub-surface application were $0.029 \%$ week $^{-1}$ and $0.041 \%$ week $^{-1}$, respectively. Potassium was the fastest nutrient released with $50 \%$ loss attained after the $2^{\text {nd }}$ and $6^{\text {th }}$ week from incorporation and surface application, respectively. Nitrogen, $\mathrm{P}, \mathrm{Ca}$, and $\mathrm{Mg}$ releases from water hyacinth incorporated in the sub-soil were significantly $(\mathrm{P} \leq$ range from 0.0001 to 0.008) high compared to surface application. Nutrients loss was in the order of $\mathrm{K}=\mathrm{Mg}>\mathrm{P}>$ $\mathrm{N}>\mathrm{Ca}$. However, results of the second experiment showed that incorporation of water hyacinth residues significantly $(\mathrm{P} \leq 0.001)$ decreased $\mathrm{pH}$ (by about 27\%) and hydraulic conductivity (by 40
\end{abstract}

$46 \%$ ). Also, cation exchange capacity and organic $\mathrm{C}$ were significantly increased by about 23 and $100 \%$, respectively. The study concluded that application of water hyacinth could be one of the good alternatives for improving quality of arid soils.

\section{INTRODUCTION}

Aquatic plants like water hyacinth have invaded rivers and lakes of many East African countries. Woomer (1997) estimated that it accumulated at power plants of approximately $900 \mathrm{Mg}$ dry weight and mechanically removed every 14 to 20 weeks interval. Disposal of water hyacinth during cleaning of rivers may have direct change of attention to its use as a soil amendment. This plant was used on vermicomposting for growth and flowering of the angiosperm crossandra (Crassandra undulaefolia) (Gajalakshmi and Abbasi, 2002). Similarly, it was used in phytoremediation experiments such as removal of heavy metals from effluents (Macek et al 2000; Susarla et al 2002; Xia and Ma, 2006).

In Sudan, water hyacinth is mainly found along the White Nile causing navigation problems, counteracting with pumping water from the Nile and increasing water loss. A local study found that incorporation of water hyacinth improved the leaching capacity of salt-affected soils and it was attributed to better aggregation. (Ahmed, 1995). Since this plant contains more than $95 \%$ water, drying besides removing areas would benefits small farms with degraded lands (Bekunda and Woomer, 1996). Incorporation of any organic residues needs information on nutrient cycling in the specific ecosystem. 
Researches on decomposition and mineralization rates of added organic matter to the soils were concentrated in humid ecosystems with high biotic activities (e.g. Cochran 1990; Taylor et al 1991; Issac and Nair, 2005). Studies on extreme dry conditions of arid and semiarid were carried in North America (e.g. Whiteford et al 1988) and the Negeve Desert (Hamadi et al 2000). Attempts to study decomposition and nutrient release under desert conditions of Africa are greatly lacking. Therefore, the objectives of this study were (1) to determine decomposition and nutrients dynamics of a decomposing water hyacinth under arid conditions and (2) to determine the effect of incorporation of dried water hyacinth on some selected properties of a sandy loam soil.

\section{MATERIALS AND METHODS}

\section{Experiment 1: Decomposition and Nutrient Release from Water Hyacinth}

This experiment (21 November, 2005 to 21 March, 2006) was carried out in a farm located in the peripheries of the capital (Khartoum, lat$15^{\circ} 73^{-} \mathrm{N}$, long- $\left.32^{\circ} 13^{-} \mathrm{E}\right)$. According to Soil Survey Staff (1996), the soil ( $\mathrm{pH} 7.3$, TN $0.1 \mathrm{~g} \mathrm{~kg}^{-1}$, O.C. $0.3 \mathrm{~g} \mathrm{~kg}^{-1}$, CEC cmole (+) $\mathrm{kg}^{-1}$, ECe $1.6 \mathrm{dS}$ $\mathrm{m}^{-\mathrm{I}}$, hydraulic conductivity $10.2 \mathrm{~cm} \mathrm{hr}^{-1}$, soluble $\mathrm{Ca}, \mathrm{Mg}, \mathrm{Na}$ and $\mathrm{K}$ are 3.4, 0.8, 0.9 and $0.12 \mathrm{meq}$ $\mathrm{L}^{-1}$, respectively, Sand $72 \%$, Silt $9.7 \%$, clay $18.3 \%$ ) of the site was classified as hyperthermic, sandy loam, mixed, gypsic cambi orthid. The climate is semi-arid with total annual rainfall (July September) of about $155.5 \mathrm{~mm}$, average maximum and minimum temperatures are 41.6 and $15{ }^{\circ} \mathrm{C}$, respectively (Fig. 1).

\section{Plant Materials}

Water hyacinth (Eichornia crassipes) was collected from the White Nile in the village of Gezira Aba, White Nile province (about $300 \mathrm{~km}$ south Khartoum). The whole plant material (roots, seudo- stem and leaves) were removed from the White Nile, air-dried on mats beside the Nile, packed and transported to the study site. Immediately after they were received, a sub sample was taken, oven-dried $\left(60-70^{\circ} \mathrm{C}\right)$ for $48 \mathrm{hrs}$, crushed (0.5 mm sieve) and stored dry for characterization. Analysis of C, N, K, P, Ca and Mg were done by the Institute of Plant Nutrition, University of Giessen, Germany. Plant material contained $1.07 \%$ TN, $25.8 \%$ total C (C/N: 24.1$), 0.199 \%$ total P,
$1.9 \% \mathrm{~K}, 1.69 \% \mathrm{Ca}, 0.77 \% \mathrm{Mg}$, ash content $39.5 \%$, lignin of $7.5 \%$ and $\mathrm{pH}$ ( $1 \mathrm{~g}$ in $10 \mathrm{ml}$ distilled water) of 6.0 .

\section{Field Decomposition}

Decomposition (mass loss) of the water hyacinth and nutrient release were monitored between 21/11/2005 and 21/3/2006 using the litter bags method (Anderson and Ingram, 1993). Nylon bags of 15 X $20 \mathrm{~cm}$ dimensions with mesh size of the $2 \mathrm{~mm}$ were used. One side of the bag was left open for faunal activity. Exactly $30.8 \mathrm{~g}$ air dried weight from water hyacinth was placed into each bag. A total number of bags were 24 and were buried in the top $30 \mathrm{~cm}$ depth (sub-surface) and a similar number (i.e. 24 bags) were placed on the soil surface in the same site with a label inserted inside the bag. Water was sprayed on the field and soil moisture content (gravimetric) during decomposition was determined. Soil temperature of the 0-30 cm depth was measured every two weeks using soil thermometers during the experiment and it was recorded to vary from 22 to $30^{\circ} \mathrm{C}$ (average of 25) whereas soil moisture content varied from 2 to $7 \%$ (average of $4 \%$ ). At each sampling date 2 , $4,6,8,10,12,14$, and 16 weeks, three bags were retrieved, and the soil attached was carefully removed then after, each bag was placed inside a paper envelope and transferred to the laboratory for analysis. The remaining residues were oven dried at $65-75^{\circ} \mathrm{C}$ until constant weight. The soil attached to the dried material was carefully brushed out and the weight of the remaining residue was recorded, ground to pass $0.5 \mathrm{~mm}$ sieve and analyzed for remaining $\mathrm{C}, \mathrm{N}, \mathrm{K}, \mathrm{P}, \mathrm{Ca}$ and $\mathrm{Mg}$ contents.

Experiment Two: Short-term effect of incorporation of water hyacinth on some properties of a sandy soil and early establishment of fodder sorghum (Sorghum bicolor).

The hypothesis of this experiment was based on the results of the first experiment. Accordingly, it was decided to incubate the water hyacinth for 12 weeks before studying the establishment of the crop.

\section{Experimental Layout}

This experiment was setup in the glasshouse of the Faculty of Agriculture, University of Khartoum, Sudan. The soil (2 mm sieve) was obtained from the surface $(0-30 \mathrm{~cm})$ of the same farm 


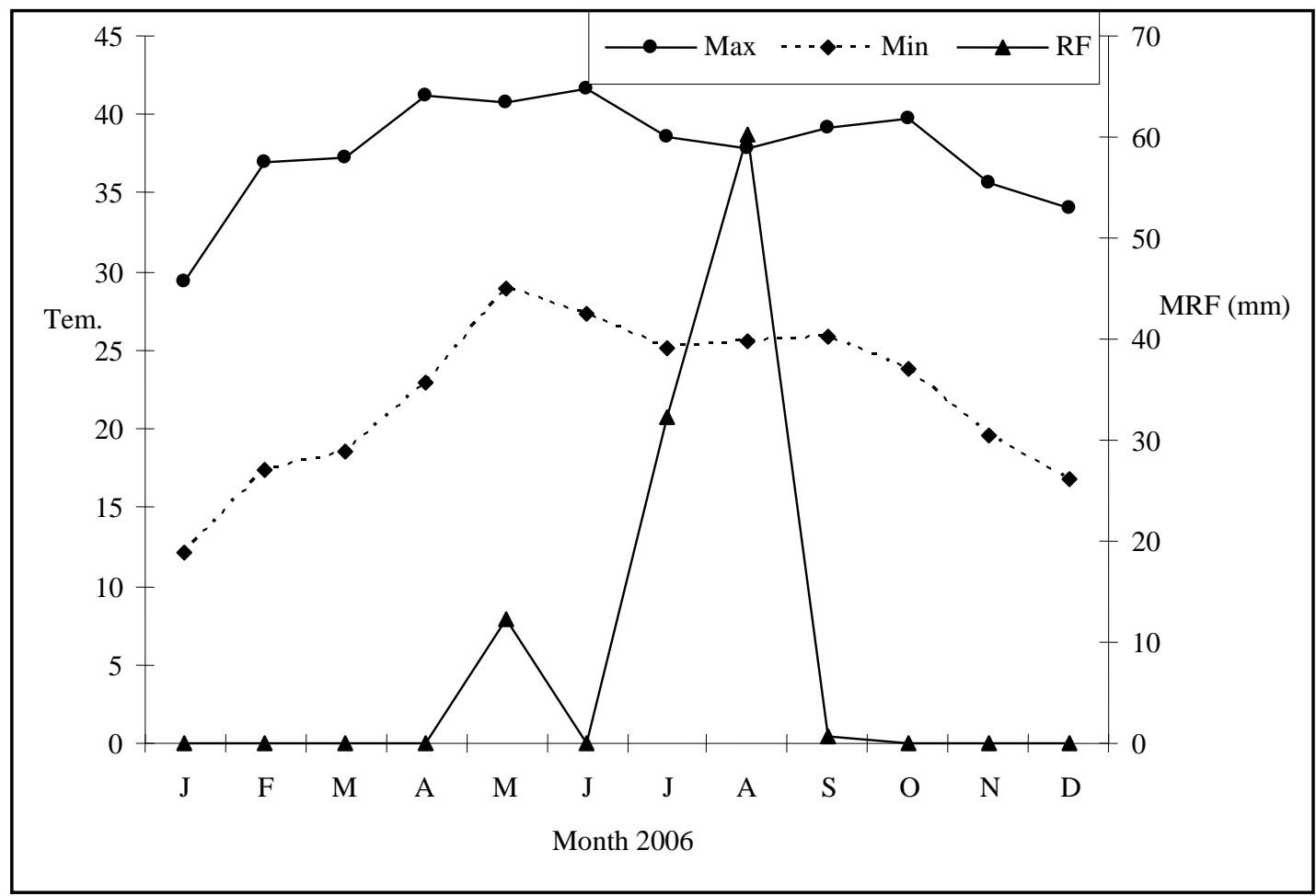

Fig. 1. Mean monthly rainfall $(\mathrm{mm})$, maximum and minimum temperatures $\left({ }^{\circ} \mathrm{C}\right)$ during the decomposition period (experiment 1)

where experiment was done. Water hyacinth of experiment one was used in this study. Plant material was oven-dried $\left(65-70^{\circ} \mathrm{C}\right.$ for two days) and crushed (1 mm size) before evenly incorporation into the whole soil of polyethylene bag. Exactly 5 $\mathrm{kg}$ soil was added to a polyethylene bag $(18 \mathrm{~cm}$ wide) with the following treatments:

1. Control (no fertilizer no water hyacinth)

2. Recommended inorganic fertilizer $(87 \mathrm{~kg} \mathrm{~N}$ as urea, $45 \mathrm{~kg} \mathrm{P}_{2} \mathrm{O}_{5}$ as TSP / ha)

3. Water hyacinth (6.7 t $\mathrm{DM} \mathrm{ha}^{-1}$; equivalent amount of recommended $\mathrm{N}$ )

The experiment was arranged in Randomized Complete Blocks Design (RCBD) with 3 replications (18 experimental units). Bags were placed in the glasshouse (1 May 2006) and only those with plant materials were regularly irrigated (every 7 days) with amount of tap water that was equivalent to the field capacity of the soil $(26.7 \%)$. After 12 weeks (1 August 2006), the recommended inorganic fertilizer dose was applied and all bags were sown with 3 seeds of fodder sorghum (Sorghum bicolor) and irrigation (every 3 days). After 4 weeks from sowing, plants were cut $(2 \mathrm{~cm}$ above the soil surface) with a blade, placed inside an envelope and dry matter was recorded after drying at $65-70^{\circ} \mathrm{C}$ for two days. The soil of each bag was air-dried, roots were removed and transferred to the laboratory for determination of $\mathrm{pH}, \mathrm{CEC}, \mathrm{OC}$, $\mathrm{TN}$, hydraulic conductivity, ECe and soluble cations ( $\mathrm{K}, \mathrm{Ca}, \mathrm{Mg}$ and $\mathrm{Na}$ ) as previously described. ANOVA analysis with Least Significant Difference (LSD) was performed for determination of statistical variations between treatments (Gomez and Gomez, 1984).

\section{Plant and Soil analysis}

Total $\mathrm{N}$ in the soil and plant was determined using the semi-macro Kjeldahl method described by Bremner and Mulvaney (1982). Soil and plant organic $\mathrm{C}$ was determined by the modified Walkley Black method (Walkley and Black, 1934). Plant samples were ashed at $150^{\circ} \mathrm{C}$ first, then at $550^{\circ} \mathrm{C}$ and dissolved in $5 \mathrm{~N} \mathrm{HCL}$ and analyzed for K (also soil soluble) by flame photometer, $\mathrm{P}$ by spectrophotometer and $\mathrm{Ca}, \mathrm{Mg}$ and $\mathrm{Na}$ (also soil soluble) by titration against ethylene diamine tetra acetic acid (Chapman and Pratt, 1982) and lignin was determined by the acid detergent fiber method (Goering and Van Soest, 1970). Electrical conductivity of the saturation 
extract $\left(\mathrm{EC}_{\mathrm{e}}\right)$ was measured according to Richard (1954), Soil pH (paste) was measured using knick digital $\mathrm{pH}$-meter, and hydraulic conductivity was measured according to Kirkham and Powers (1972).

\section{Statistical Analysis}

Rates of mass loss and nutrient release of residues (expressed as percent remaining of initial contents) were calculated using the single exponential model $\mathrm{W}_{\mathrm{t}}=\mathrm{W}_{0} \mathrm{e}^{-\mathrm{kt}}$ proposed by Olson (1963) where $W_{t}$ is the mass loss at time (t) in weeks, $\mathrm{W}_{0}$ is the initial dry matter or nutrient pool and $\mathrm{k}$ is the rate constant $\left(\%\right.$ week $\left.^{-1}\right)$. The time required for $50 \%\left(\mathrm{~T}_{0.5}\right)$ and $95 \%\left(\mathrm{~T}_{0.95}\right)$ were equal to $0.693 / \mathrm{k}$ and $3 / \mathrm{k}$, respectively. Statistical differences between surface application and incorporation were determined by subjecting the data to the analysis of variance (ANOVA) and means separation was conducted using T-Test (SAS, 1985).

\section{RESULTS AND DISCUSSION}

\section{Decay and nutrient release}

\section{Weight loss}

Remaining dry matter weight (\%) during 16 weeks of incubation period is shown in Fig. (2). Statistical analysis showed that during all samplings, loss from sub-surface application was significantly $(\mathrm{P} \leq 0.01-0.0005)$ greater than those of surface application. After the end of the incubation $\left(16^{\text {th }}\right.$ week) DM that remained in sub-surface application $(47.2 \%)$ was significantly $(\mathrm{P} \leq 0.0005)$ lower than that determined in surface application $(60.9 \%)$ by about $22 \%$. Decomposition rate constant (k) and time to $50 \%, 95 \%$ weight loss were significantly higher when plant materials were buried than left on the surface (Table 1). Aerobic decay of fresh water hyacinth was very fast in the study carried out by Woomer et al (2000) in the semi-arid tropics of Kenya (total annual rain-fall during the study period of 214-373 mm) compared to $0 \mathrm{~mm}$ in this study. However, regular sprinkling of water raised soil moisture to $5-8 \%$ which was far below the optimum for biological activities. In the study of Woomer et al (2000), time to 50\% weight loss in mulch application found to be 3 weeks compared to 24 weeks in our's. This big difference shows that under arid conditions, soil moisture availability and organic matter content are important for biotic activity. Better soil-plant contact would possibly justify fast decay in incorporated water hyacinth compared to surface application (Jama and Nair, 1996) or improved moisture content (Hamadi et al 2000). However, this slow decomposition especially at surface application would provide good opportunity for use in protecting surface soils against erosion. Subsurface placement of bags resembles residue incorporation by tillage. The latter was earlier considered as a regulator or driving variable enhancing elemental cycling in agroecosystem (Buchanan and King, 1993).

\section{Nutrients dynamics}

Nitrogen remained during decomposition showed a consistent release in both placements (Fig. 3a). Table (1) shows that $\mathrm{N}$ release rate from sub-surface $(0.074)$ was significantly $(\mathrm{P} \leq 0.08$ $0.0001)$ higher than that from surface placement (0.049). By the end of the incubation period, about $29 \%$ and $44 \%$ remained in sub-surface and surface placements, respectively. Percent $\mathrm{N}$ remained during the incubation period did not exceeded $100 \%$ which indicates absence of immobilization. Moreover, $\mathrm{N}$ concentrations measured during all samplings were lower than the initial content (Table 2). Kinetic rate constants showed that after half of the material was finished expressed as $\mathrm{T}(0.5)$, loss of $\mathrm{N}$ from sub-surface placement was more pronounced compared to surface application. This is clear as when $50 \%$ depletion occurred in surface application, longer time was needed for apparent 95\% fate of the material. Goyal et al (2005) showed that during 90 days composting of water hyacinth, $\mathrm{N}$ concentration was never higher than the initial. Other study found reported that non composted water hyacinth was found to be a viable substrate for mushroom cultivation despite the fact that their $\mathrm{C} / \mathrm{N}$ ratio (24) was above the threshold (20) of $\mathrm{N}$ mineralization (Murugesan et al 1995). In this study, absence of $\mathrm{N}$ immobilization could possibly be due to the low lignin: $\mathrm{N}$ ratio. Lignin: N ratio was reported to be highly correlated with litter decay (Cortez et al 1996 and Mafongoya et al 1998). Maithani et al (1998) reported that due to low lignin and $\mathrm{C} / \mathrm{N}$ ratio, $\mathrm{N}$ was found to be released from a decomposing tropical tree (Schima khasiana) leaves $(\% \mathrm{~N}$ of $1.09 \%$ ). This pattern of $\mathrm{N}$ release reflects that recycling of such plant materials would not cause $\mathrm{N}$ starvation to growing plants and hence offers better alternative for amelioration of poor desert sandy soils. Both treatments showed that actual 


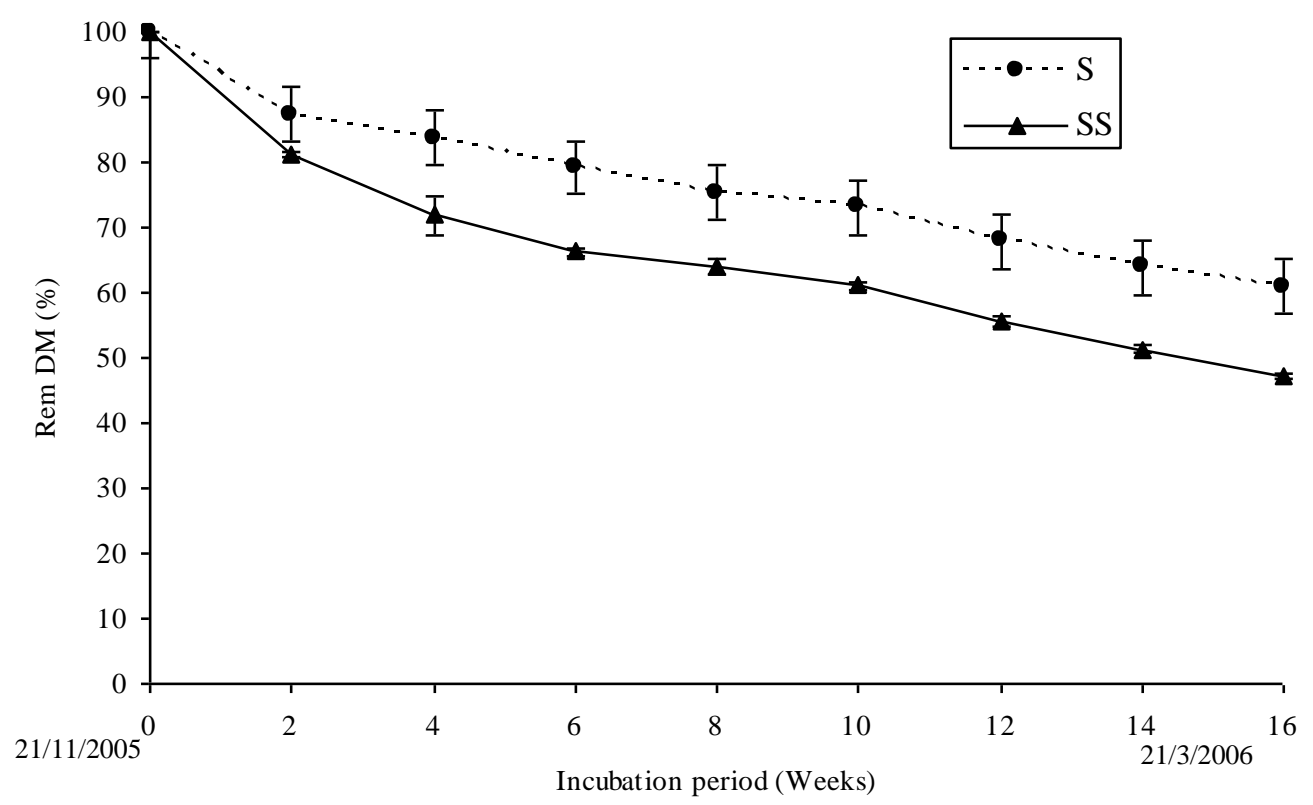

Fig. 2. Remaining dry matter weight (\%) during decomposition of water hyacinth in surface (S) and sub-surface (SS) application. (Vertical bars are standard deviations)

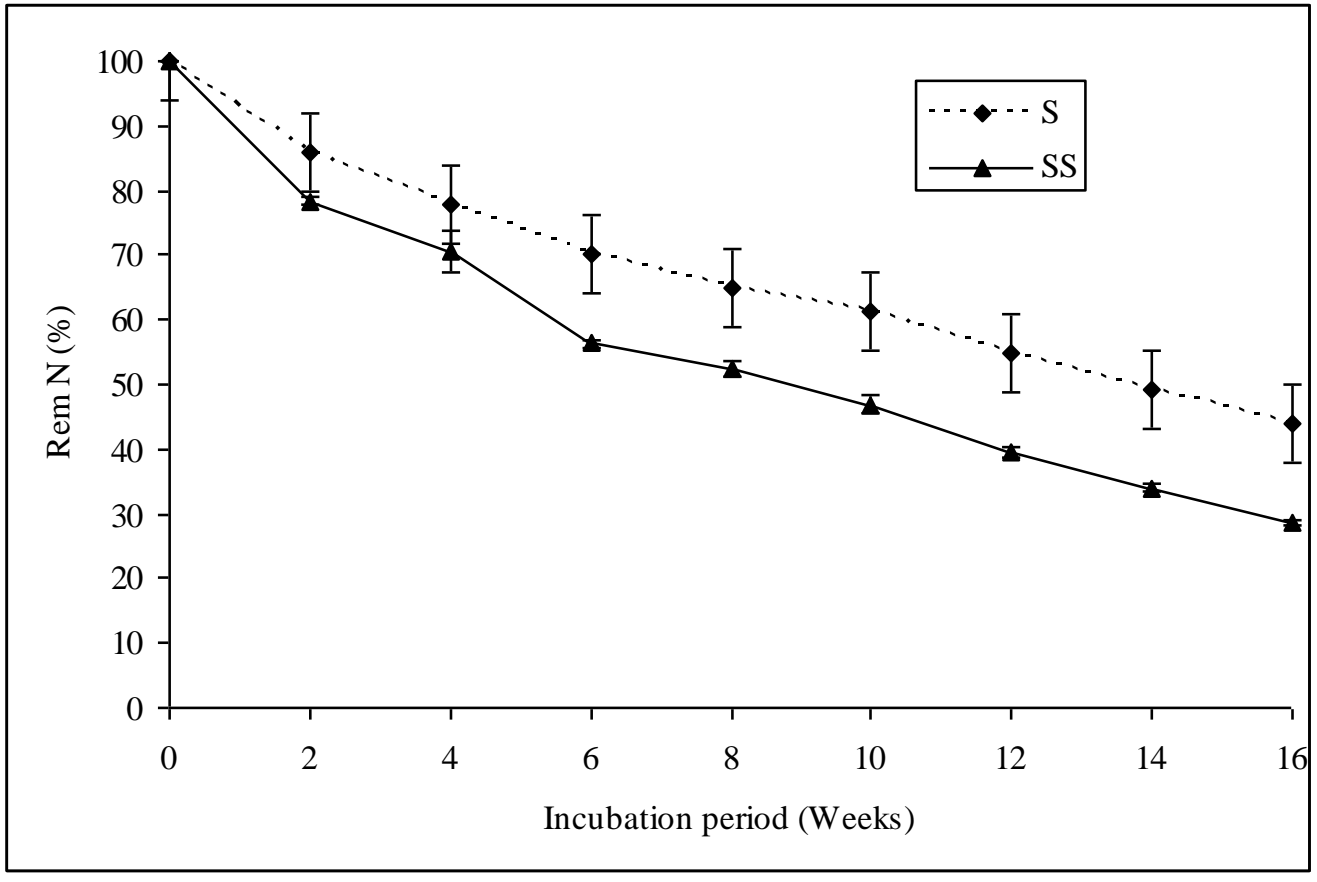

Fig. 3a. Changes in $\mathrm{N}$ during decomposition of water hyacinth in surface (S) and sub-surface (SS) application. (Vertical bars are standard deviations) 
Table 1. Decomposition rate constant $\left(\mathrm{k}\right.$, week $\left.\mathrm{k}^{-1}\right)$, half-time $\left(\mathrm{T}_{0.5}\right)$ and time required for $95 \%\left(\mathrm{~T}_{0.95}\right)$ loss of dry matter and nutrients

\begin{tabular}{|c|c|c|c|c|c|c|c|c|}
\hline \multirow{2}{*}{ Parameter } & \multicolumn{4}{|c|}{$\mathrm{k}$} & \multicolumn{2}{|c|}{$\mathrm{T}_{(0.5)}$} & \multicolumn{2}{|c|}{$\mathrm{T}_{(0.95)}$} \\
\hline & $\mathrm{S}$ & SS & Probability & $r^{2}$ & $\mathrm{~S}$ & SS & $S$ & SS \\
\hline DM & 0.0285 & 0.0414 & 0.0007 & 0.96 & 24 & 17 & 105 & 72 \\
\hline $\mathrm{N}$ & 0.0485 & 0.0737 & 0.0005 & 0.99 & 14 & 9 & 62 & 41 \\
\hline $\mathrm{P}$ & 0.1179 & 0.1753 & 0.008 & 0.96 & 6 & 4 & 25 & 17 \\
\hline $\mathrm{K}$ & 0.0580 & 0.0686 & 0.0002 & 0.89 & 12 & 10 & 52 & 44 \\
\hline $\mathrm{Ca}$ & 0.0444 & 0.0679 & 0.0009 & 0.94 & 16 & 10 & 68 & 44 \\
\hline $\mathrm{Mg}$ & 0.0779 & 0.1063 & 0.0001 & 0.96 & 9 & 6 & 39 & 28 \\
\hline
\end{tabular}

K decomposition rate constant, DM dry matter, S surface application, SS sub-surface incorporation

$\mathrm{P}$ remained by the end on the period $(5-15 \%$ was less than the corresponding amount of $\mathrm{N}$ (Fig. $\mathbf{3 b}$ ). Also, $\mathrm{P}$ concentration did not show that $\mathrm{P}$ was limiting element during decomposition (Table 2). Nutrients changes showed that $\mathrm{P}$ is the most element released with quite higher rates (Table 2). Earlier Woomer et al (2000) calculated that 50\% loss of P from whole plant of water hyacinth was attained after about 2 weeks compared to 4 to 6 weeks in this study. Although $\mathrm{K}$ is well known as a non structural element, its release from the decomposing water hyacinth was not very rapid as expected. However, initially (i.e. after 2 weeks), K was the only element determined to have higher mobility, i.e $35-48 \%$ loss (Fig. 3c). It is quite clear that $\mathrm{K}$ concentration in the remained material (Table 2) was abruptly decreased after 2 weeks while there was a steady release during later stages. It might possibly be that regular water spraying was not enough to leach $\mathrm{K}$ during later stages as occurred at the beginning of the experiment. We can not say that $\mathrm{K}$ release from water hyacinth is a function of its distribution among plant parties. However, it is important that mobility of nutrients from decomposing organic materials applied to sandy soils with low adsorption capacities should be slow to decrease chances of $\mathrm{K}$ leaching. Generally, in both placements, Ca was the least nutrient released. By the end of the incubation period, about $78 \%$ of the initial concentration remained (Fig. 3d). The order of nutrient release could be as follows: $\mathrm{P}>\mathrm{Mg}>\mathrm{K}>\mathrm{N}=\mathrm{Ca}$ (surface application) and $\mathrm{P}>\mathrm{Mg}>\mathrm{N}>\mathrm{K}=\mathrm{Ca}$ (sub-surface placement) Fig. (3a, b, c, d and e). Quite similar release pattern was earlier found elsewhere (Luna-Orea et al 1996; Rutigliano et al 1998).

\section{Effects on soil properties}

Short-term effects of incorporation of water hyacinth on soil properties are shown in Table (3). Addition of water hyacinth residues decreased final soil $\mathrm{pH}$ (after 12 weeks) from 7.3 to 5.3 (i.e. $27 \%$ reduction). Previous researches on impact of residue application on soil $\mathrm{pH}$ shows different results (Xu et al 2006). They varied from increase (Marschner and Noble, 2000) or decrease, increase or remained unchanged ( $X u$ et al 2006). It is well known that almost all results showed $\mathrm{pH}$ increase of acid soils. However, it seems that initial soil $\mathrm{pH}$ will greatly influence the direction of change. Within the acid range, Xu et al (2006) observed that $\mathrm{pH}$ of a sandy soil (initial $\mathrm{pH}$ 5.06) decreased by application of many residues. Similarly, Tang and Yu (1999) found $\mathrm{pH}$ decrease in soils with moderate acidity. Although, in this study excess cations of water hyacinth were not determined, we speculate that $\mathrm{pH}$ decrease could possibly be due to residue type of acidic nature (6.0) and initial soil pH. Since in our experiment, plants were sown in the bags, $\mathrm{NH}_{4}$ uptake is associated with the excretion of $\mathrm{H}^{+}$(Bolan et al 1991). Cation exchange capacity and organic $\mathrm{C}$ were significantly ( $\mathrm{P} \leq 0.0001)$ increased by about 23 and $100 \%$, respectively. On the other hand, hydraulic conductivity was significantly $(\mathrm{P} \leq 0.0001)$ decreased by $46 \%$. It is clear that temporary incorporation of water hyacinth improved soil organic matter content which eventually increased water 


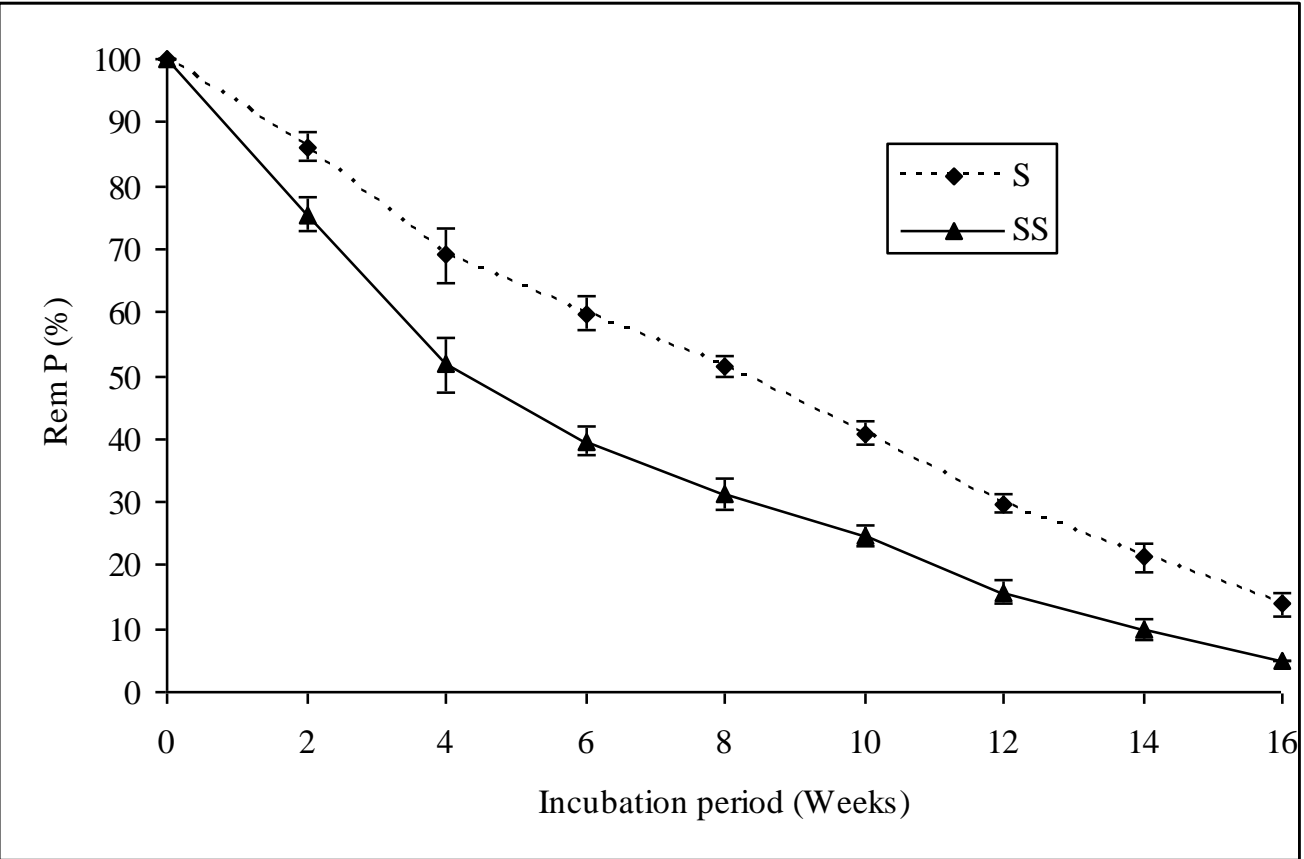

Fig. 3b. Changes in P during decomposition of water hyacinth in surface (S) and subsurface (SS) application. (Vertical bars are standard deviations)

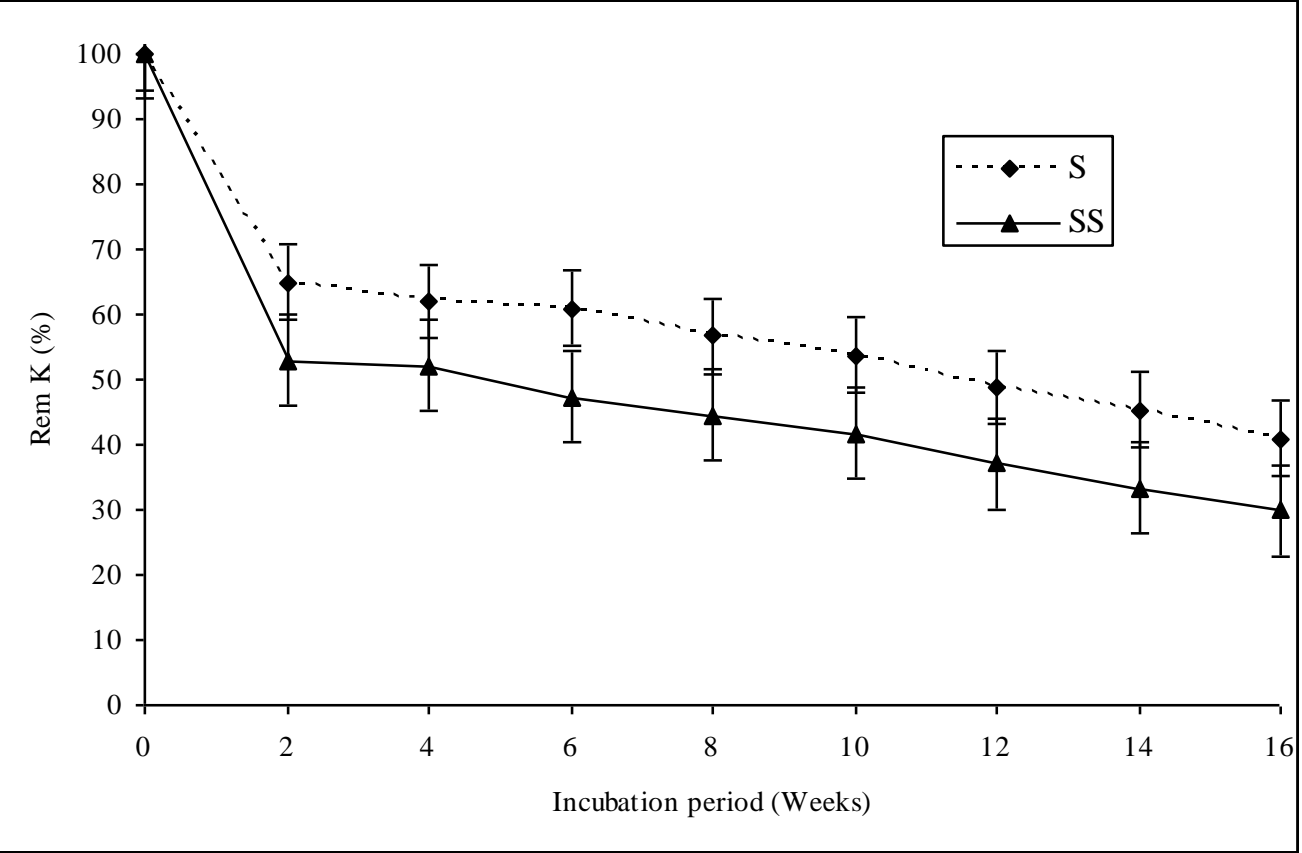

Fig. 3c. Changes in K during decomposition of water hyacinth in surface (S) and subsurface (SS) application. (Vertical bars are standard deviations) 


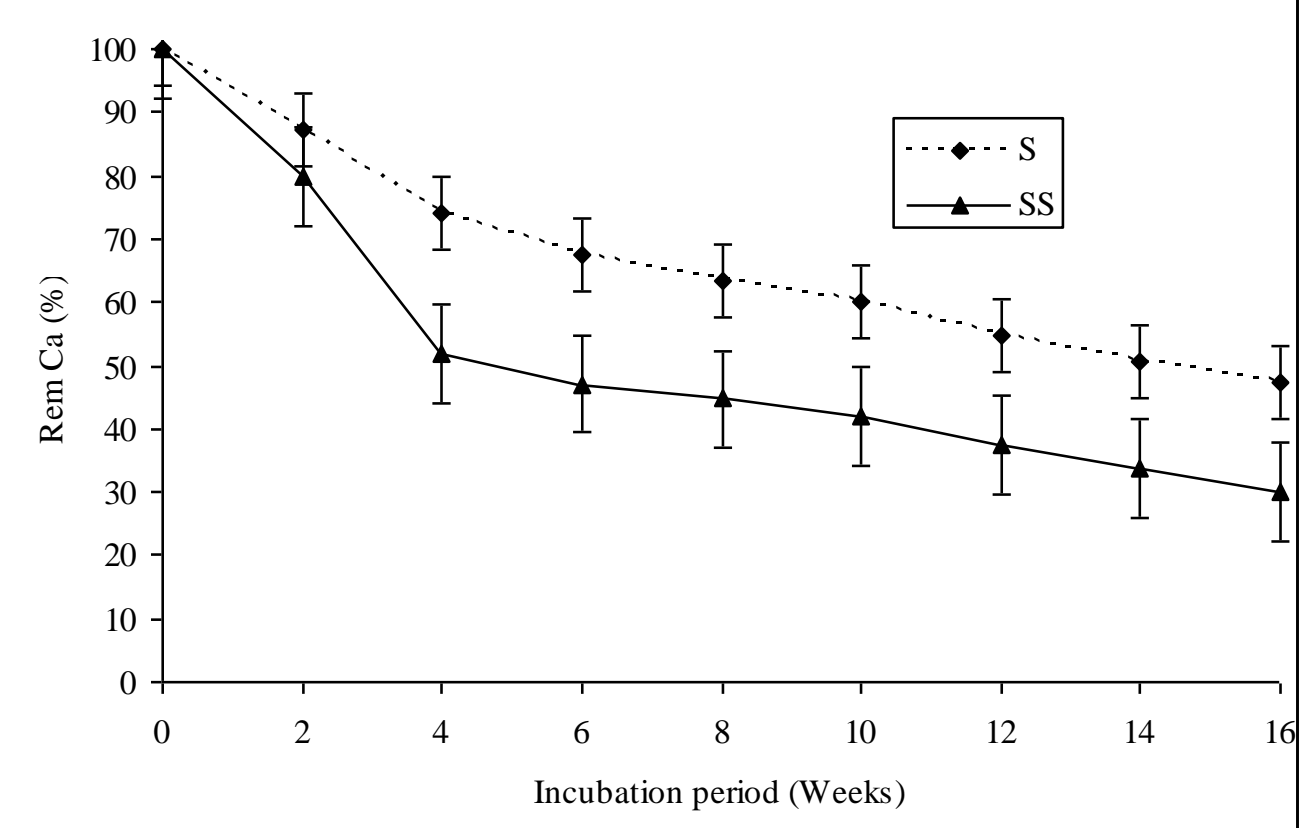

Fig. 3d. Changes in Ca during decomposition of water hyacinth in surface (S) and subsurface (SS) application. (Vertical bars are standard deviations)

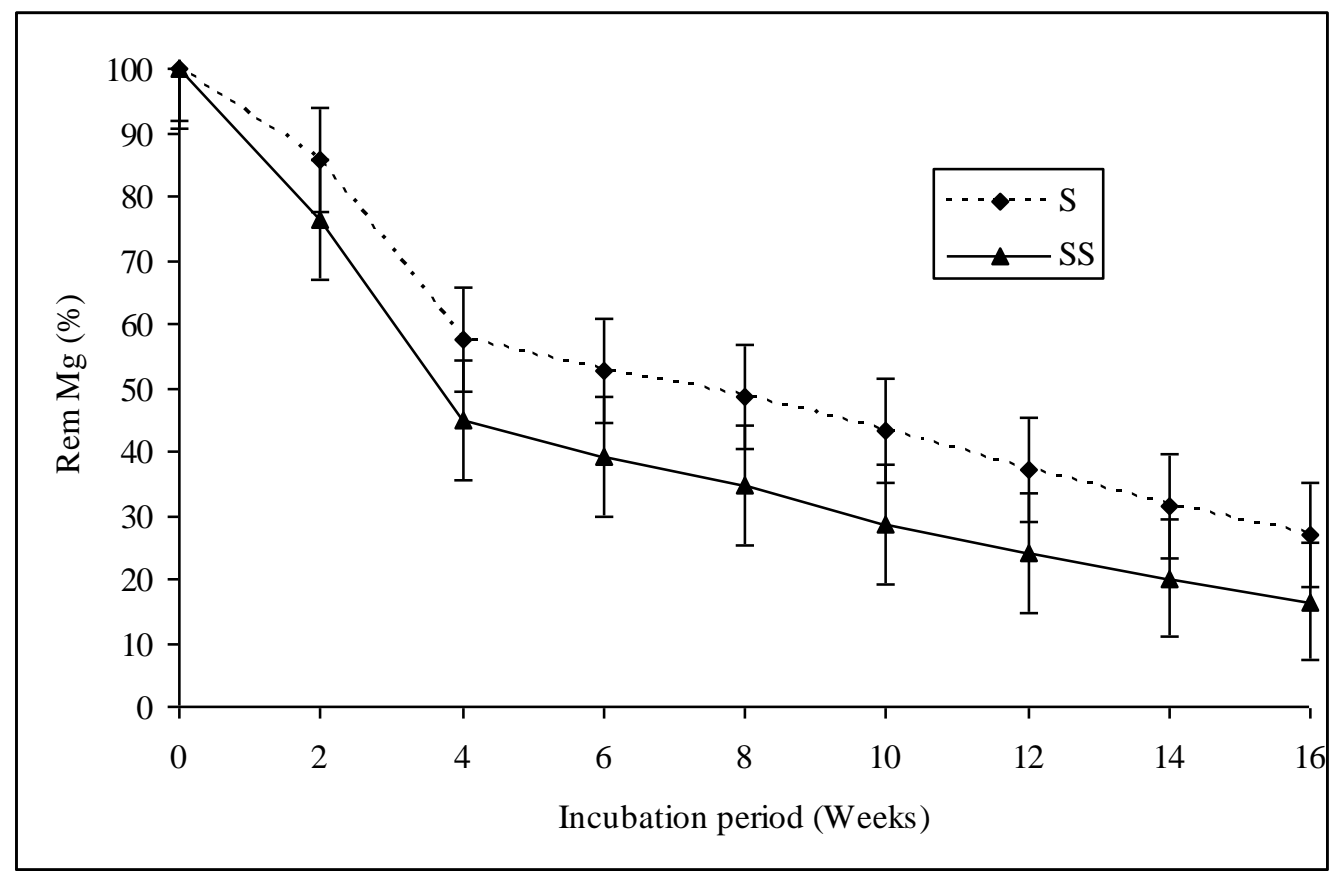

Fig. 3e. Changes in $\mathrm{Mg}$ during decomposition of water hyacinth in surface $(\mathrm{S})$ and subsurface (SS) application. (Vertical bars are standard deviations) 
Table 2. Concentration of remaining nutrients during decomposition $\left(\mathrm{g} \mathrm{kg}^{-1}\right)$

\begin{tabular}{|cccccc|}
\hline \multirow{2}{*}{ Incubation period (Weeks) } & \multicolumn{6}{c|}{ Nutrients concentrations $\left(\mathrm{g} \mathrm{kg}^{-1}\right)$} \\
\cline { 2 - 6 } & $\mathrm{N}$ & $\mathrm{P}$ & $\mathrm{K}$ & $\mathrm{Ca}$ & $\mathrm{Mg}$ \\
\hline 0 & Surface application (S) \\
2 & 10.9 & 1.9 & 18.7 & 16.8 & 7.8 \\
4 & 10.7 & 1.9 & 14.6 & 16.8 & 7.6 \\
6 & 10.1 & 1.6 & 14.3 & 14.8 & 5.4 \\
8 & 9.6 & 1.4 & 14.1 & 14.3 & 5.2 \\
10 & 9.4 & 1.3 & 13.7 & 14.1 & 5 \\
12 & 9.1 & 1.1 & 13.4 & 13.8 & 4.6 \\
14 & 8.8 & 0.8 & 13.2 & 13.6 & 4.3 \\
16 & 8.4 & 0.6 & 12.5 & 13.3 & 3.8 \\
& 7.4 & 0.4 & 11.7 & 13.1 & 3.4 \\
\hline 0 & Sub-surface application (SS) & & \\
2 & 10.9 & 1.9 & 18.7 & 16.8 & 7.8 \\
4 & 10.5 & 1.8 & 13.5 & 16.5 & 7.3 \\
6 & 9.9 & 1.4 & 13.3 & 12.1 & 4.9 \\
8 & 9.3 & 1.1 & 13.0 & 11.9 & 4.6 \\
10 & 8.9 & 0.9 & 12.7 & 11.7 & 4.2 \\
12 & 8.4 & 0.9 & 12.4 & 11.5 & 3.6 \\
14 & 7.7 & 0.5 & 12.1 & 11.3 & 3.4 \\
16 & 7.2 & 0.4 & 11.8 & 11.1 & 3.1 \\
\hline \multicolumn{7}{c}{0.6} & 0.2 & 10.9 & 10.7 & 2.7 \\
\hline
\end{tabular}

Table 3. Effect of Water hyacinth incorporation on some selected soil properties and dry matter accumulation $\left(\mathrm{g} \mathrm{plant}^{-1}\right)$ of fodder sorghum (average $\pm \mathrm{sd}$ )

\begin{tabular}{|c|c|c|c|c|c|c|c|c|c|c|c|}
\hline \multirow{3}{*}{$\begin{array}{c}\text { Treatment } \\
\text { Control }\end{array}$} & \multirow{3}{*}{$\begin{array}{c}\mathrm{pH} \\
7.3 \pm \\
0.01\end{array}$} & \multirow{3}{*}{$\begin{array}{c}\text { CEC } \\
\begin{array}{c}\mathrm{cmol}^{(+)} \\
\mathrm{kg}^{-1}\end{array} \\
\begin{array}{c}12.93 \pm \\
0.06\end{array}\end{array}$} & $\mathrm{OC}$ & $\mathrm{TN}$ & \multirow{3}{*}{$\begin{array}{c}\mathrm{HC} \\
\mathrm{Cm} \mathrm{hr}^{-1} \\
\begin{array}{c}9.73 \pm \\
0.06\end{array}\end{array}$} & \multirow{3}{*}{$\begin{array}{c}\begin{array}{c}\mathrm{ECe} \\
\mathrm{dSm}^{-1}\end{array} \\
\begin{array}{c}1.36 \pm \\
0.06\end{array}\end{array}$} & \multirow{3}{*}{$\begin{array}{c}\mathrm{K} \\
\\
0.08 \pm \\
0.01\end{array}$} & \multirow{2}{*}{\multicolumn{2}{|c|}{$\begin{array}{l}\mathrm{Ca} \\
\text { meq } \mathrm{L}^{-1}\end{array}$}} & \multirow{3}{*}{$\begin{array}{c}\mathrm{Na} \\
\\
0.7 \pm \\
0.03\end{array}$} & \multirow{3}{*}{$\begin{array}{c}\begin{array}{c}\text { DM } \\
\text { (g plant }^{-1}\end{array} \\
\begin{array}{c}1.2 \pm \\
0.06\end{array}\end{array}$} \\
\hline & & & \multicolumn{2}{|c|}{$\mathrm{g} \mathrm{kg}^{-1}$} & & & & & & & \\
\hline & & & $\begin{array}{c}0.3 \pm \\
0.0\end{array}$ & $\begin{array}{c}0.12 \pm \\
0.01\end{array}$ & & & & $\begin{array}{c}2.26 \pm \\
0.06\end{array}$ & $\begin{array}{c}0.63 \pm \\
0.06\end{array}$ & & \\
\hline $\begin{array}{c}\text { Water } \\
\text { hyacinth }\end{array}$ & $\begin{array}{l}5.3 \pm \\
0.01\end{array}$ & $\begin{array}{c}15.90 \pm \\
0.23\end{array}$ & $\begin{array}{l}0.6 \pm \\
0.06\end{array}$ & $\begin{array}{c}0.12 \pm \\
0.01\end{array}$ & $\begin{array}{c}5.23 \pm \\
0.06\end{array}$ & $\begin{array}{c}1.33 \pm \\
0.0\end{array}$ & $\begin{array}{c}0.07 \pm \\
0.01\end{array}$ & $\begin{array}{c}2.23 \pm \\
0.12\end{array}$ & $\begin{array}{c}0.56 \pm \\
0.06\end{array}$ & $\begin{array}{l}0.7 \pm \\
0.02\end{array}$ & $\begin{array}{l}1.3 \pm \\
0.10\end{array}$ \\
\hline $\begin{array}{l}\text { Inorganic } \\
\text { fertilizer }\end{array}$ & $\begin{array}{l}7.3 \pm \\
0.01\end{array}$ & $\begin{array}{c}12.96 \pm \\
0.68\end{array}$ & $\begin{array}{l}0.3 \pm \\
0.01\end{array}$ & $\begin{array}{c}0.15 \pm \\
0.01\end{array}$ & $\begin{array}{c}8.73 \pm \\
0.15\end{array}$ & $\begin{array}{c}1.43 \pm \\
0.06\end{array}$ & $\begin{array}{c}0.08 \pm \\
0.01\end{array}$ & $\begin{array}{c}2.33 \pm \\
0.06\end{array}$ & $\begin{array}{c}0.64 \pm \\
0.06\end{array}$ & $\begin{array}{l}0.7 \pm \\
0.01\end{array}$ & $\begin{array}{l}1.8 \pm \\
0.06\end{array}$ \\
\hline C.V. & 0.12 & 1 & 8.4 & - & 1.2 & - & - & - & - & - & 5.1 \\
\hline $\mathrm{P}$ & 0.0001 & 0.0001 & 0.0001 & - & 0.0001 & - & - & - & - & - & 0.0001 \\
\hline LSD & 0.0163 & 0.28 & 0.0067 & NS & 0.19 & NS & NS & NS & NS & NS & 0.1489 \\
\hline
\end{tabular}

CEC: Cation exchange capacity, OC: Organic carbon, TN: Total N, HC: Hydraulic conductivity, ECe: Electrical conductivity of the saturation extract

C.V.: Coefficient of variability, P: Probability at 0.05 level, LSD: Lease Significant Difference

Arab Univ. J. Agric. Sci., 16(1), 2008 
holding capacity and thereby reduced downwards movement of water. Application Organic materials were earlier found to improve soil water content through increase of negative charges (Khaleel $\boldsymbol{e t}$ al 1981; Barzegar et al 2002). We speculate that absence of significant effects on soil soluble cations, CEC and dry matter accumulation could be due to sub-optimal amount added. However, most important that during removal of water hyacinth, incorporation of this plant waste to sandy soils away from the Nile will certainly reduce irrigation water needed. This study showed that during field decomposition of water hyacinth residues, $\mathrm{N}$ and $\mathrm{P}$ (most important nutrients), were not limiting the decomposition process.

\section{REFERENCES}

Ahmed, A.B. (1995). Impact of Soil Water Management on Salt Leaching and Forage Sorghum Growth in Shambat Soil. p. 84. M.Sc. Thesis, University of Khartoum, Shambat, Sudan. Anderson, J.M. and J.S. Ingram (1993). Tropical Soil and Fertility: A Handbook of Methods. CAB International, Walling-ford, UK.

Barzegar, A.R.; A. Yousefi and A. Daryashenas (2002). The effect of addition of different amounts and types of organic materials on soil physical properties and yield of wheat. Plant and Soil 247: 295-301.

Bekunda, M.A. and P.L. Woomer (1996). Organic resource management in banana-based cropping systems of the Lake Victoria Basin, Uganda. Agriculture Ecosystems and Environment 59: 171-180.

Bolan, N.S.; M.J. Hedley and R.E. White (1991). Processes of soil acidification during nitrogen cycling with emphasis on legume based pastures. Plant and Soil 134: 53-63.

Bremner, J.M. and C.S. Mulvaney (1982). Nitrogen-Total. In: Methods of Soil Analysis. Part 2. Chemical and Microbiological Properties. Agronomy Monograph No. 9 ( $2^{\text {nd }}$ Edition). pp. 595622. Eds. Page, A.L.; R.H. Miller and D.R. Keeny. American Society of Agronomy, Madison, WI.

Buchanan, M. and L.D. King (1993). Carbon and phosphorous losses from decomposing crop residues in no-till and conventional till agroecosystems. Agronomy Journal. 85: 631-638.

Chapman, H.D. and F.P. Pratt (1982). Determination of minerals by titration. Methods of Analysis for Soils, Plant and Water, $2^{\text {nd }}$ Ed. pp. 169170. California University, Agriculture Division, U.S.A.,
Cochran, V.L. (1990). Decomposition of barley straw in subarctic soil in the field. Biology and Fertility of Soils 10: 227-232.

Cortez, J.; M.J. Demard; P. Bottner and L. Jocteur Monrozier (1996). Decomposition of Mediterranean leaf litters: A microcosim experiment investigating relationships between decomposition rates and litter quality. Soil Biology and Biochemistry 28: 443-452.

Gajalakshmi, S. and S.A. Abbasi (2002). Effect of the application of water hyacinth compost/ vermicompost on the growth and flowering of Crossandra undulaefolia, and on several vegetable. Bioresource Technology 85: 197-199.

Goering, H.K. and P.J. van Soest (1970). Forage Fiber Analysis. In: Agriculture Handbook. No. 379, USDA, Washington.

Gomez, K.A. and A.A. Gomez (1984). Statistical Procedures for Agricultural Research. 2nd Ed., John Wiley and Sons, New York, USA.

Goyal, S.; S.K. Dhull and K.K. Kapoor (2005). Chemical and biological changes during composting of different organic wastes and assessment of compost maturity. Bioresource Technology 96: 1584-1591.

Hamadi, Z.; Y. Steinberger; P. Kutiel; H. Lavee and G. Barness (2000). Decomposition of Avena sterilis litter under arid conditions. Journal of Arid Environment 46: 281-293.

Issac, R.S. and M.A. Nair (2005). Biodegradation of leaf litter in the warm humid tropics of Kerala, India. Soil Biology and Biochemistry 37: 1656-1664.

Jama, B.A. and P.K.R. Nair (1996). Decomposition and nitrogen mineralization patters of Leucaena leucocephala and Cassia siamea mulch under tropical semiarid conditions in Kenya. Plant and Soil 179: 275-285.

Khaleel, R.K.; R. Reddy and M.R. Overcash (1981). Changes in soil physical properties due to organic waste application: A review. Journal of Environmental Quality 110: 133-141.

Kirkham, D. and W.L. Powers (1972). Darcy's law, Laplacce's equation and boundary value problems. Advanced Soil Physics, p. 46, WileyInterscience, NY.

Luna-Orea, P.; M.G. Wagger and M.L. Gumpertz (1996). Decomposition and nutrient release dynamics of tropical legume cover crop. Agronomy Journal 88: 758-764.

Macek, T.; M. Mackova and J. Kas (2000). Exploitation of plants for the removal of organics in environmental remediation. Biotechnology Advanced 18: 23-34. 
Mafongoya, P.L.; P.K.R. Nair and B.H. Dzowela (1998). Mineralization of nitrogen from decomposing multipurpose trees as affected by their chemical composition. Biology and Fertility of Soils 27: 143-148.

Maithani, K.; A. Arunachalam; R.S. Tripathi and H.N. Pandey (1998). Influence of leaf litter quality on $\mathrm{N}$ mineralization in soils of subtropical humid forest regrowths. Biology and Fertility of Soils 27: 44-50.

Marschner, B. and A.D. Noble (2000). Chemical and biological processes leading to the neutralisation of acidity in soil incubated with litter materials. Soil Biology and Biochemistry 32: 805-813. Murugesan, A.G.; P. Vijayalakshmi; N. Sukumaran and C. Maraippan (1995). Utilization of water hyacinth for oyster mushroom cultivation. Bioresource Technology. 51: 97-98.

Olson, J.S. (1963). Energy storage and the balance of products and decomposers in ecological systems. Ecology 44: 322-331.

Richard, L.A. (1954). Diagnosis and Improvement of Saline and Alakli Soils. Handbook 60, USDA, Washington, D.C.

Rutigliano, F.A.; A. Alfani; L. Bellini and A. Virzo De Santo (1998). Nutrient dynamics in decaying leaves of Fagus sylvatica $\mathrm{L}$. and needles of Abies slba Mill. Biology and Fertility of Soils 27: 119-126.

SAS. (1985). SAS User"s Guide: Statistics, $5^{\text {th }}$ Ed., SAS Institute, Cary, NC, U.S.A.

Soil Survey Staff. (1996). Keys to Soil Taxonomy, $7^{\text {th }}$ Edition. United States Department of Agriculture, Washington, D.C.

Susarla, S.; V.F. Medina and S.C. McCutcheon (2002). Phytoremediation: an ecological solution to organic chemical contamination. Ecological Engineering 18: 647-658.

Tang, C. and Q. Yu (1999). Impact of chemical composition of legume residues and initial on soil $\mathrm{pH}$ change of a soil after residue incorporation. Plant and Soil 215: 29-38.

Taylor, B.R.; C.E. Parsons; W.J.F. Parsons and D. Parkinson (1991). Substrate control of litter decomposition in four Rocky Mountain coniferous forests. Canadian Journal of Botany 69: 22422250.

Walkley, A. and I.A. Black (1934). An examination of the Degtjareff method for determining soil organic matter and a proposed modification of the chromic acid method. Soil Science 37: 29-38.

Whiteford, W.G.; K. Stinnet and Y.Steinberger (1988). Effects of rainfall supplementation on microarthopods on decomposing roots in the Chihuahuan Desert. Pedobiologia 31: 147-155.

Woomer, P.L. (1997). Managing water hyacinth invasion through integrated control and utilization perspectives for lake Victoria. African Journal of Crop Science 5: 309-324.

Woomer, P.L.; R. Muzira; D. Bwamiki; D. Mutetikka; A. Amoding and M.A. Bekunda (2000). Biological management of water hyacinth waste in Uganda. Biological Agriculture and Horticulture 17: 181-196.

Xia, H. and X. Ma (2006). Phytoremediation of ethion by water hyacinth (Eichornia crassipes) from water. Bioresource Technology 97: 10501054.

Xu, J.M..; C. Tang and Z.L. Chen (2006). The role of plant residues in $\mathrm{pH}$ changes of acid soils differing in initial $\mathrm{pH}$. Soil Biology and Biochemistry 38: 709-719. 